\title{
Analisis Website Program Kreativitas Mahasiswa (PKM Center) Universitas Ahmad Dahlan Menggunakan WebQual 4.0
}

\section{Analysis of Student Creativity Program Website at Ahmad Dahlan University Using WebQual 4.0}

\author{
Dinan Yulianto ${ }^{1}$, Taufiq Ismail ${ }^{2}$ \\ Universitas Ahmad Dahlan, Indonesia
}

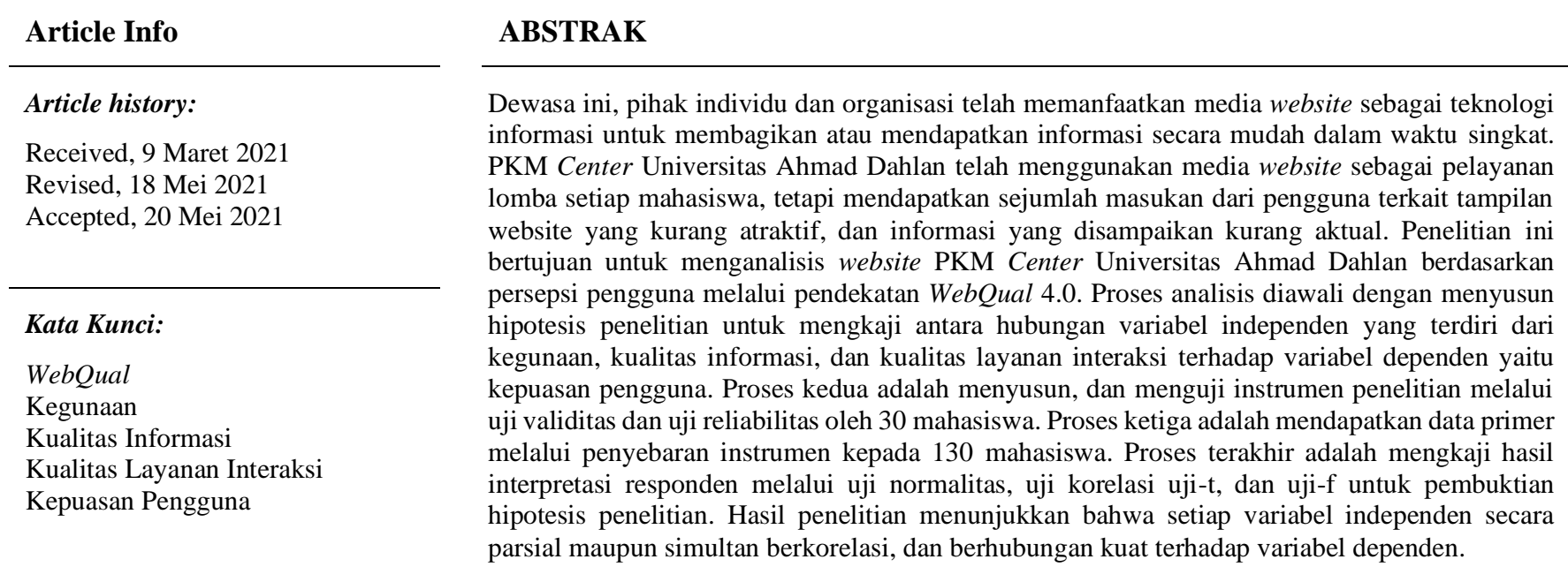

\section{ABSTRACT}

Keywords:

WebQual

Usability

Information Quality

Service Interaction Quality

User's Satisfaction

Nowadays, individuals and organizations have been used website media as information technology to get easily share or obtain information in a short time. PKM Center Universitas Ahmad Dahlan has applied website media as a service for each student's competition activities but has received several inputs from users regarding the appearance of the website that is not attractive, and the information displayed is not actual. This research aims to analyze the PKM Center UAD website based on user perceptions with the WebQual 4.0 approach. The analysis process begins with compiling research hypotheses to test the relationship between the independent variables, namely usability, information quality, and service interaction quality on the dependent variable or user satisfaction. The second process is compiling and testing research instruments with validity tests and reliability tests by 30 students. The third process is to obtain primary data through the dissemination of research instruments to 130 students. The final process is to examine the results of the respondent's interpretation through the normality test, correlation test, $t$-test, and f-test to prove the research hypothesis. The results showed that each independent variable partially or simultaneously correlated and strongly related to the dependent variable.

This is an open access article under the CC BY-SAlicense.

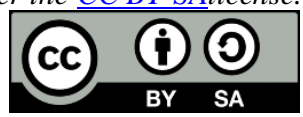

\footnotetext{
Penulis Korespondensi:

Dinan Yulianto,

Program Studi S1Teknik Informatika,

Universitas Ahmad Dahlan,

Email:dinan.yulianto@tif.uad.ac.id
} 


\section{PENDAHULUAN}

Dewasa ini, hampir setiap aspek dalam kehidupan manusia tidak terlepas dari penggunaan teknologi, termasuk dalam hal ini adalah penggunaan teknologi informasi [1][2]. Penggunaan teknologi informasi secara masif tidak hanya oleh perorangan tetapi juga digunakan oleh organisasi seperti instansi pendidikan.

Sebuah website adalah salah satu bentuk teknologi informasi untuk mendapatkan informasi secara mudah dalam waktu singkat [3]. Peran website dalam suatu organisasi tidak terbatas sebagai media informasi, tetapi juga sebagai salah satu indikator dalam menilai kualitas. Website suatu organisasi perlu mendapat perhatian secara berkala untuk menjaga konsistensi [4], dan meningkatkan kualitas sehingga tercapai penilaian yang baik.

Universitas Ahmad Dahlan sebagai salah satu perguruan tinggi selalu berupaya memenuhi kebutuhan mahasiswa dalam pelayanan aktivitas lomba melalui media sosial dan website yang secara khusus dikelola oleh PKM Center. Humas PKM Center menyampaikan bahwa media website yang digunakan mendapatkan sejumlah masukan dari pengguna terkait tampilan antarmuka yang kurang atraktif, dan konten informasi yang disampaikan kurang bersifat aktual. Intensitas pelayanan aktivitas lomba juga secara masif dilakukan melalui media sosial yang rentan terjadi kesalahpahaman interpretasi informasi.

Berdasarkan fenomena yang terjadi, maka perlu dilakukan kajian terhadap setiap faktor yang menjadi prioritas pengembangan sebagai upaya dalam meningkatkan kualitas website PKM Center. Proses kajian dapat dilakukan melalui implementasi model WebQual 4.0 dengan instrumen evaluasi yang berfokus pada persepsi pengguna terhadap kualitas website [5]. Instrumen WebQual 4.0 juga dibangun secara komprehensif yang menjamin kehandalan, serta validitas kualitas evaluasi [6].

Model WebQual 4.0 telah melalui beberapa fase iterasi selama penyusunan instrumen evaluasi yang terbentuk menjadi tiga dimensi utama yaitu kegunaan, kualitas informasi, dan kualitas layanan interaksi [7][8][9][10][11]. Berbagai penelitian telah mengadaptasi model WebQual untuk menilai kualitas website seperti pada domain website pemerintah [12][13][14], website jasa layanan [15][16][17], dan website pendidikan [18][19][20].

Peneliti [18] menganalisa salah satu website universitas untuk mengetahui pengaruh dimensi utama atau variabel independen (kegunaan, kualitas informasi, dan layanan interaksi) terhadap variabel dependen (kepuasan pengguna). Peneliti [19] menganalisa website yang dimiliki oleh Universitas Telkom untuk mengetahui kesenjangan antara harapan dengan persepsi pengguna, dan menetapkan atribut yang menjadi prioritas untuk dioptimalkan. Peneliti [20] menganalisa $e$-learning yang dimiliki oleh STMIK Dipanegara Makasar untuk mengetahui tingkat persentase penerimaan pengguna terhadap setiap dimensi atau variabel WebQual.

Hasil kajian dari peneliti [18][19][20] menjadi acuan dari penelitian ini, tetapi terdapat beberapa perbedaan seperti objek penelitian adalah website PKM Center Universitas Ahmad Dahlan, dimensi penelitian adalah 3 variabel dari model WebQual 4.0, instrumen penelitian disesuaikan dengan jenis portal berita resmi layanan aktivitas lomba dan menghilangkan unsur transaksi dari model WebQual 4.0. Perbedaan terhadap peneliti [18] terletak pada dimensi kualitas layanan interaksi yang memiliki 6 butir pertanyaan dengan menghapus unsur transaksi, dan pada dimensi kepuasan pengguna yang memiliki 3 butir pertanyaan atau menambahkan 2 butir pertanyaan baru yang relevan.

Peneliti [19] menggunakan 5 variabel independen dan peneliti [20] menggunakan 4 variabel independen, tetapi tidak membahas dimensi kepuasan pengguna sebagai variabel dependen sehingga kajian komparasi tidak dapat dilakukan. Perbedaan terhadap peneliti [19] terletak pada dimensi kegunaan yang memiliki 7 butir pertanyaan dan dimensi kualitas layanan interaksi yang memiliki 6 butir pertanyaan atau jumlah pertanyaan yang lebih sedikit. Perbedaan terhadap peneliti [20] juga terdapat pada dimensi kegunaan yang memiliki 7 butir pertanyaan dan dimensi kualitas layanan interaksi yang memiliki 5 butir pertanyaan atau jumlah pertanyaan yang lebih sedikit dari penelitian ini.

Penelitian ini bertujuan untuk mengimplementasi model WebQual 4.0 terhadap objek penelitian yang baru yaitu website PKM Center Universitas Ahmad Dahlan. Penelitian ini fokus pada proses menganalisa pengaruh, dan mengetahui signifikansi dari setiap variabel independen terhadap variabel dependen. Intisari permasalahan yang akan dibuktikan dalam penelitian ini adalah pengaruh variabel independen secara parsial serta simultan terhadap variabel dependen, dan signifikansi yang bersesuaian antara variabel independen terhadap variabel dependen. Hasil dari penelitian dapat menjadi referensi keberlanjutan penelitian dalam mengevaluasi prioritas variabel pengembangan website PKM Center.

\section{METODE PENELITIAN}

Penelitian ini merupakan kategori penelitian deskriptif dengan pendekatan kuantitatif. Proses mendapatkan data primer dilakukan melalui penyebaran kuesioner kepada responden. Penyusunan kuesioner penelitian mengadaptasi model WebQual 4.0 sebagai kerangka konseptual pengukuran kualitas website. Model WebQual 4.0 yang diadaptasi dalam menyusun kuesioner penelitian telah melalui beberap fase iterasi, fokus pembahasan terhadap persepsi pengguna [5], dan bersifat komprehensif yang menjamin kehandalan serta validitas kualitas evaluasi [6]. Model WebQual 4.0 terdiri atas tiga dimensi utama atau variabel independen yaitu kegunaan, kualitas informasi, dan kualitas layanan interkasi (Gambar 1). Proses interpretasi responden terhadap 
instrumen penelitian didasarkan pada skala likert yang terdiri dari lima pilihan mulai dari sangat tidak setuju sampai sangat setuju.

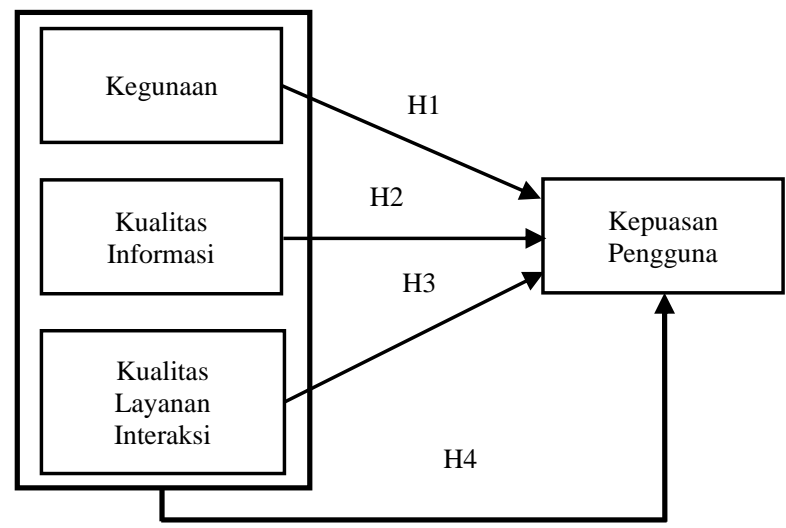

Gambar 1. Kerangka Konseptual Pengukuran Kualitas Website

Penilaian kualitas website dilihat berdasarkan pengaruh hubungan antara variabel independen terhadap variabel dependen, sehingga terbentuk hipotesis dalam penelitian ini yaitu:

H1: Kegunaan memiliki hubungan positif dan signifikan terhadap kepuasan pengguna.

H2: Kualitas informasi memiliki hubungan positif dan signifikan terhadap kepuasan pengguna.

H3: Kualitas layanan interaksi memiliki hubungan positif dan signifikan terhadap kepuasan pengguna.

H4: Kegunaan, kualitas informasi, dan kualitas layanan interaksi memiliki hubungan positif dan signifikan terhadap kepuasan pengguna.

Tahapan analisis dalam menguji hipotesis untuk menghasilkan kesimpulan penelitian dimulai dari uji validitas dan reliabilitas instrumen, uji normalitas, uji korelasi, uji- $t$, dan uji-f. Detail seluruh tahapan penelitian disajikan pada Gambar 2.

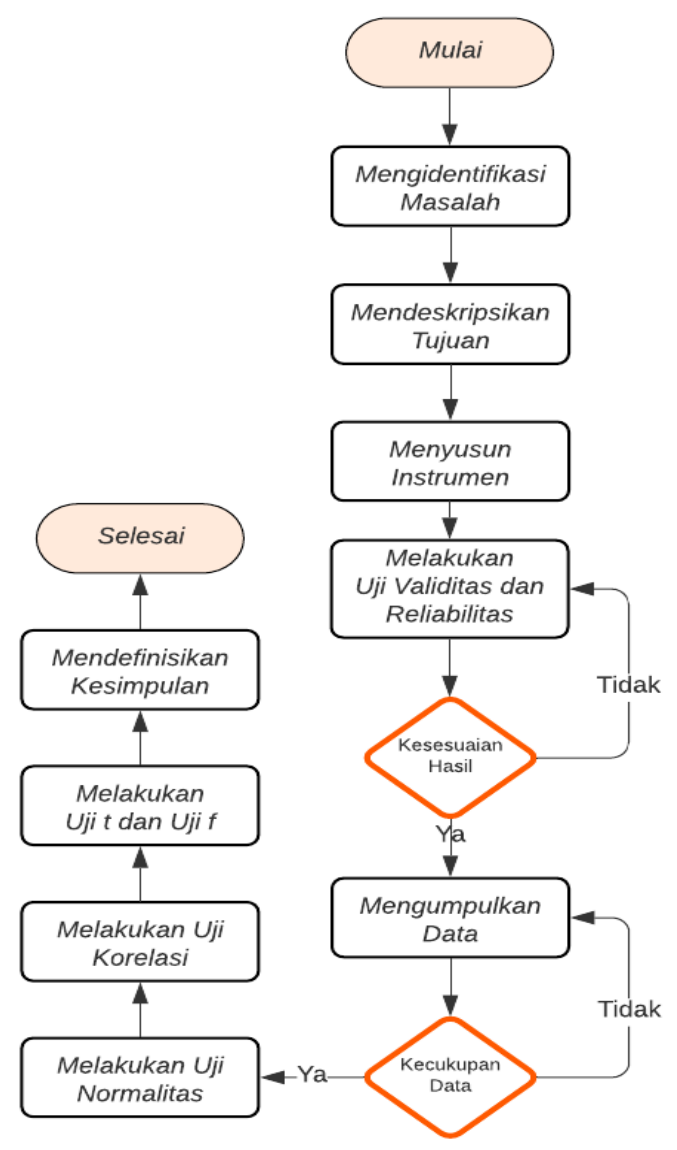

Gambar 2. Diagram Penelitian 


\section{HASIL DAN ANALISIS}

\subsection{Desain Penelitian}

Penelitian ini bersifat deskriptif kuantitatif untuk menganalisa pengaruh dan mengetahui signifikansi dari setiap variabel independen terhadap variabel dependen pada model WebQual 4.0. Objek penelitian yang akan dikaji dengan mengadaptasi model WebQual 4.0 adalah website PKM Center Universitas Ahmad Dahlan sebagai media pelayanan setiap aktivitas lomba mahasiswa.

\subsection{Instrumen Penelitian}

Instrumen penelitian ini terdiri atas 24 butir pertanyaan yang disusun mengadaptasi model WebQual 4.0. Model WebQual 4.0 memiliki tiga dimensi atau variabel utama yaitu [9]:

1. Kegunaan: Dimensi ini fokus pada proses mengidentifikasi kemudahan pengguna dalam berinteraksi terhadap website untuk mencapai tujuan secara efektif dan efisien.

2. Kualitas Informasi: Dimensi ini fokus pada proses mengidentifikasi kualitas konten atau informasi yang ditampilkan secara akurat, aktual, dan koheren.

3. Kualitas Layanan Interaksi: Dimensi ini fokus pada proses mengidentifikasi kualitas layanan interaksi yang erat berhubungan tentang kepercayaan dan keamanan.

4. Kepuasan Pengguna: Dimensi tambahan yang fokus pada proses mengidentifikasi keseluruhan dimensi kualitas website.

Dimensi kegunaan, kualitas informasi, dan kualitas layanan interaksi dikategorikan menjadi variabel independen, sedangkan dimensi kepuasan penguna dikategorikan menjadi variabel dependen. Hasil penyusunan instrumen penelitian ini ditampilkan Tabel 1.

Tabel 1. Instrumen Penelitian

\begin{tabular}{|c|c|c|}
\hline Dimensi & Kode & Pertanyaan \\
\hline \multirow{8}{*}{$\begin{array}{l}\text { Kegunaan } \\
\text { (X1) }\end{array}$} & $\mathrm{X} 1.1$ & Website PKM Center mudah dipelajari \\
\hline & $\mathrm{X} 1.2$ & Website PKM Center mudah digunakan \\
\hline & $\mathrm{X} 1.3$ & Website PKM Center memiliki url yang mudah ditemukan \\
\hline & $\mathrm{X} 1.4$ & Website PKM Center memiliki struktur menu yang terorganisir dengan baik \\
\hline & $\mathrm{X} 1.5$ & Website PKM Center memiliki tampilan yang menarik \\
\hline & $\mathrm{X} 1.6$ & Website PKM Center memiliki fungsional sebagai jenis website layanan aktivitas lomba mahasiswa \\
\hline & $\mathrm{X} 1.7$ & Website PKM Center memiliki kompetensi yang baik \\
\hline & $\mathrm{X} 1.8$ & Website PKM Center menciptakan pengalaman yang positif \\
\hline \multirow{7}{*}{$\begin{array}{l}\text { Kualitas } \\
\text { Informasi } \\
\quad \text { (X2) }\end{array}$} & $\mathrm{X} 2.1$ & Website PKM Center menyediakan informasi yang jelas dan akurat \\
\hline & $\mathrm{X} 2.2$ & Website PKM Center menyediakan informasi yang terpecaya \\
\hline & $\mathrm{X} 2.3$ & Website PKM Center menyediakan informasi yang bersifat aktual \\
\hline & $\mathrm{X} 2.4$ & Website PKM Center menyediakan informasi yang mudah dipahami \\
\hline & $\mathrm{X} 2.5$ & Website PKM Center menyediakan informasi yang detail dan berimbang \\
\hline & $\mathrm{X} 2.6$ & Website PKM Center menyediakan informasi yang relevan dengan aktivitas lomba \\
\hline & $\mathrm{X} 2.7$ & $\begin{array}{l}\text { Website PKM Center menyediakan informasi dalam format yang pantas } \\
\text { (struktur kalimat, jenis/ukuran font, dan lain) }\end{array}$ \\
\hline \multirow{6}{*}{$\begin{array}{c}\text { Kualitas } \\
\text { Layanan } \\
\text { Interaksi } \\
\quad \text { (X3) }\end{array}$} & $\mathrm{X} 3.1$ & Website PKM Center memiliki reputasi yang baik \\
\hline & $\mathrm{X} 3.2$ & Website PKM Center memberikan kenyamanan dalam menyampaikan data pribadi \\
\hline & $\mathrm{X} 3.3$ & Website PKM Center menjaga data/informasi yang bersifat pribadi secara baik \\
\hline & $\mathrm{X} 3.4$ & Website PKM Center memberikan penjelasan yang akurat terhadap tanggapan pengguna \\
\hline & $\mathrm{X} 3.5$ & Website PKM Center memberikan penjelasan secara cepat terdahap tanggapan pengguna \\
\hline & $\mathrm{X} 3.6$ & Website PKM Center memberikan layanan sesuai kebutuhan pengguna \\
\hline \multirow{3}{*}{$\begin{array}{c}\text { Kepuasan } \\
\text { Pengguna } \\
(\mathbf{Y}) \\
\end{array}$} & $\mathrm{Y} 1$ & Saya merasa puas menggunakan website PKM Center \\
\hline & $\mathrm{Y} 2$ & Saya akan mengunjungi lagi website PKM Center \\
\hline & Y3 & Saya akan merekomendasikan website PKM Center kepada pihak lain \\
\hline
\end{tabular}

\subsection{Responden Penelitian}

Penelitian ini terdiri atas dua kelompok responden dengan jumlah sampel minimum adalah 30 responden. Penentuan ukuran sampel yang layak dalam penelitian sejumlah 30 responden didasarkan pada hasil kajian [21][22], dan penentuan karakteristik responden didasarkan pada kompetensi dalam perancangan, pengembangan, dan pengujian suatu produk software. Kelompok pertama bertujuan untuk menguji nilai validitas dan reliabilitas dari instrumen penelitian oleh 30 mahasiswa semester 6 yang tergabung pada kelas rekayasa website. Kelompok kedua bertujuan untuk membuktikan hipotesis penelitian oleh 130 mahasiswa dari semester 4 dan semester 6 yang tergabung pada kelas rekayasa kebutuhan sistem, pemrograman mobile, dan pemrograman web dinamis pada periode studi ganjil 2020/2021. Informasi demografi 160 responden penelitian ditampilkan Tabel 2. 
Tabel 2. Demografi Responden

\begin{tabular}{|c|c|c|c|}
\hline & Kode & Jumlah & Persentase (\%) \\
\hline \multirow{2}{*}{ Jenis Kelamin } & Laki-laki & 114 & $71.75 \%$ \\
\hline & Perempuan & 46 & $28.75 \%$ \\
\hline \multirow{2}{*}{ Semester } & Semester 4 & 85 & $53.12 \%$ \\
\hline & Semester 6 & 75 & $46.88 \%$ \\
\hline \multirow{4}{*}{ Bidang Studi } & Rekayasa Kebutuhan Sistem & 48 & $30.00 \%$ \\
\hline & Rekayasa Website & 30 & $18.75 \%$ \\
\hline & Pemrograman Web Dinamis & 42 & $26.25 \%$ \\
\hline & Pemrograman Mobile & 40 & $25.00 \%$ \\
\hline
\end{tabular}

\subsection{Pengujian Validitas Instrumen Penelitian}

Tahapan setelah penyusunan instrumen penelitian adalah pengujian validitas instrumen yang bertujuan untuk menilai derajat ketepatan dan kecermatan instrumen dalam menghasilkan kesimpulan. Proses pengujian validitas instrumen dilakukan menggunakan suatu aplikasi statistik SPPS melalui analisa hubungan antara nilai $r$-tabel terhadap nilai $r$-hitung (pearson correlation). Jika nilai $r$-hitung lebih besar dari nilai $t$-tabel, maka instrumen yang disusun bersifat valid. Hasil pengujian validitas oleh 30 responden ditampilkan Tabel 3.

Tabel 3. Hasil Uji Validitas Instrumen

\begin{tabular}{ccccc}
\hline Kode & r-tabel & Pearson Correlation & Sig. (2-tailed) & Hasil \\
\hline X1.1 & 0.361 & 0.478 & 0.008 & Valid \\
\hline X1.2 & 0.361 & 0.430 & 0.018 & Valid \\
\hline X1.3 & 0.361 & 0.379 & 0.039 & Valid \\
\hline X1.4 & 0.361 & 0.696 & 0.000 & Valid \\
\hline X1.5 & 0.361 & 0.680 & 0.000 & Valid \\
\hline X1.6 & 0.361 & 0.633 & 0.000 & Valid \\
\hline X1.7 & 0.361 & 0.750 & 0.000 & Valid \\
\hline X1.8 & 0.361 & 0.623 & 0.000 & Valid \\
\hline X2.1 & 0.361 & 0.821 & 0.000 & Valid \\
\hline X2.2 & 0.361 & 0.507 & 0.004 & Valid \\
\hline X2.3 & 0.361 & 0.620 & 0.000 & Valid \\
\hline X2.4 & 0.361 & 0.612 & 0.000 & Valid \\
\hline X2.5 & 0.361 & 0.746 & 0.000 & Valid \\
\hline X2.6 & 0.361 & 0.638 & 0.000 & Valid \\
\hline X2.7 & 0.361 & 0.460 & 0.010 & Valid \\
\hline X3.1 & 0.361 & 0.693 & 0.000 & Valid \\
\hline X3.2 & 0.361 & 0.621 & 0.000 & Valid \\
\hline X3.3 & 0.361 & 0.493 & 0.006 & Valid \\
\hline X3.4 & 0.361 & 0.693 & 0.000 & Valid \\
\hline X3.5 & 0.361 & 0.531 & 0.003 & Valid \\
\hline X3.6 & 0.361 & 0.678 & 0.001 & Valid \\
\hline Y1 & 0.361 & 0.814 & 0.000 & Valid \\
\hline Y2 & 0.361 & 0.794 & 0.000 & Valid \\
\hline Y3 & 0.361 & 0.756 & 0.000 & Valid \\
\hline & & & \\
\hline & & & & \\
\hline
\end{tabular}

Setiap butir instrumen memiliki nilai $r$-hitung (pearson correlation) lebih besar dari nilai $r$-tabel, atau nilai signifikansi lebih kecil dari "0.05". Hasil pengujian validitas menyatakan bahwa setiap butir instrumen bersifat valid dengan tingkat kemungkinan kesalahan $5 \%$.

\subsection{Pengujian Reliabilitas Instrumen Penelitian}

Tahapan lain setelah penyusunan dan pengujian validitas instrumen adalah pengujian reliabilitas instrumen dengan tujuan untuk menilai konsistensi instrumen dalam menghasilkan kesimpulan yang relatif sama pada keberlanjutan penelitian. Pengujian reliabilitas instrumen dilakukan melalui analisa hubungan antara nilai Cronbach's alpha dengan ketetapan nilai koefisien yaitu “0.60”[23]. Jika nilai Cronbach's alpha lebih besar dari "0.60", maka instrumen yang disusun bersifat reliabel [23]. Hasil pengujian reliabilitas oleh 30 reponden ditampilkan Tabel 4.

Tabel 4. Hasil Uji Reliabilitas Instrumen

\begin{tabular}{lcl}
\hline Dimensi & Cronbach's Alpha & Hasil \\
\hline Kegunaan & $\mathbf{0 . 7 3 5}$ & Reliabel \\
\hline Kualitas Informasi & $\mathbf{0 . 6 9 3}$ & Reliabel \\
\hline Layanan Interaksi & $\mathbf{0 . 6 5 1}$ & Reliabel \\
\hline Kepuasan Pengguna & $\mathbf{0 . 6 9 1}$ & Reliabel \\
\hline
\end{tabular}

Setiap dimensi pada instrumen memiliki nilai Cronbach's alpha lebih besar dari nilai “0.60”, maka hasil pengujian reliabilitas menyatakan bahwa instrumen penelitian bersifat reliabel. Keseluruhan hasil pengujian validitas, dan reliabilitas menegaskan bahwa instrumen penelitian bersifat akseptabel dalam mendapatkan data untuk menguji hipotesis, dan menghasilkan kesimpulan penelitian. 


\subsection{Pengujian Normalitas}

Tahapan awal setelah mendapatkan data penelitian dari 130 responden adalah pengujian normalitas yang bertujuan untuk menilai distribusi data pada suatu dimensi atau variabel. Proses pengujian normalitas dilakukan melalui pendekatan Probality Plot ( $P$-plot) dengan menguji setiap dimensi atau variabel independen terhadap variabel dependen.

Hasil uji normalitas variabel kegunaan $(X 1)$ terhadap kepuasan pengguna $(Y)$ disajikan pada Gambar 3.

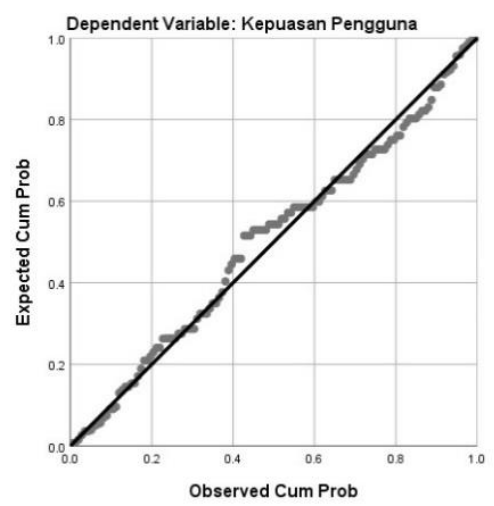

Gambar 3. Hasil Uji Normalitas P-Plot Variabel X1 dan $Y$

Hasil uji normalitas variabel kualitas informasi $(X 2)$ terhadap kepuasan pengguna $(Y)$ disajikan pada Gambar 4.

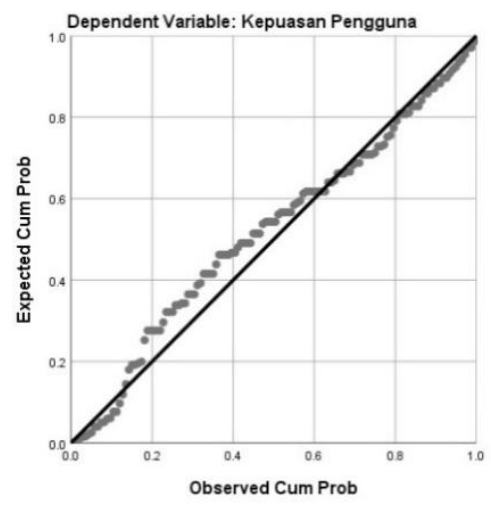

Gambar 4. Hasil Uji Normalitas P-Plot Variabel X2 dan $Y$

Hasil uji normalitas variabel kualitas layanan interaksi (X3) terhadap kepuasan pengguna (Y) disajikan pada Gambar 5.

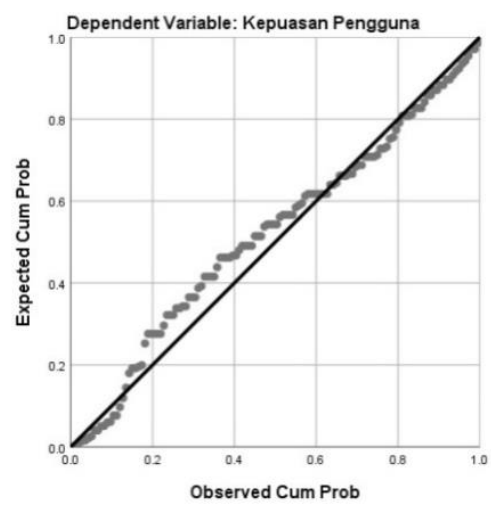

Gambar 5. Hasil Uji Normalitas P-Plot Variabel $X 3$ dan $Y$

Keseluruhan hasil pengujian normalitas dengan pendekatan Probability Plot menunjukkan bahwa data menyebar atau mengikuti di sekitar garis diagonal, maka dapat disimpulkan bahwa data terdistribusi secara normal.

\subsection{Pengujian Korelasi}

Tahap kedua setelah mendapatkan data penelitian, serta pengujian normalitas adalah pengujian korelasi yang bertujuan untuk mengetahui tingkat keeratan antara variabel independen terhadap variabel dependen. Hasil pengujian korelasi setiap variabel disajikan sebagai berikut: 
Hasil uji korealasi variabel kegunaan $(X 1)$ terhadap kepuasan pengguna $(Y)$ ditampilkan pada Tabel 5.

Tabel 5. Hasil Uji Korelasi Variabel $X 1$ dan $Y$

\begin{tabular}{|c|c|c|c|}
\hline & & Kegunaan & $\begin{array}{l}\text { Kepuasan } \\
\text { Pengguna }\end{array}$ \\
\hline \multirow{3}{*}{ Kegunaan } & Pearson Correlation & 1 & .662 \\
\hline & Sig. (2-tailed) & & .000 \\
\hline & $N$ & 130 & 130 \\
\hline \multirow{3}{*}{$\begin{array}{l}\text { Kepuasan } \\
\text { Pengguna }\end{array}$} & Pearson Correlation & 1 & .662 \\
\hline & Sig. (2-tailed) & & .000 \\
\hline & $N$ & 130 & 130 \\
\hline
\end{tabular}

Hasil uji korelasi variabel kegunaan $(X 1)$ terhadap kepuasan pengguna $(Y)$ memiliki nilai signifikansi lebih kecil dari " 0.05 ", maka antara kedua variabel memiliki hubungan atau korelasi. Nilai korelasi sebesar " 0.622 ” juga menunjukkan bahwa kedua variabel memiliki derajat hubungan yang kuat atau positif.

Hasil uji korealasi variabel kualitas informasi $(X 2)$ terhadap kepuasan pengguna $(Y)$ ditampilkan pada Tabel 6.

Tabel 6. Hasil Uji Korelasi Variabel $X 2$ dan $Y$

\begin{tabular}{|c|c|c|c|}
\hline & & $\begin{array}{l}\text { Kualitas } \\
\text { Informasi }\end{array}$ & $\begin{array}{l}\text { Kepuasan } \\
\text { Pengguna }\end{array}$ \\
\hline \multirow{3}{*}{$\begin{array}{l}\text { Kualitas } \\
\text { Informasi }\end{array}$} & Pearson Correlation & 1 & .654 \\
\hline & Sig. (2-tailed) & & .000 \\
\hline & $N$ & 130 & 130 \\
\hline \multirow{3}{*}{$\begin{array}{l}\text { Kepuasan } \\
\text { Penggua }\end{array}$} & Pearson Correlation & .654 & 1 \\
\hline & Sig. (2-tailed) & .000 & \\
\hline & $N$ & 130 & 130 \\
\hline
\end{tabular}

Hasil uji korelasi variabel kualitas informasi $(X 2)$ terhadap kepuasan pengguna $(Y)$ memiliki nilai signifikansi lebih kecil dari "0.05", maka antara kedua variabel memiliki hubungan atau korelasi. Nilai korelasi sebesar "0.654" juga menunjukkan bahwa kedua variabel memiliki derajat hubungan yang kuat atau positif.

Hasil uji korealasi variabel kualitas layanan interaksi $(X 3)$ terhadap kepuasan pengguna $(Y)$ ditampilkan pada Tabel 7.

Tabel 7. Hasil Uji Korelasi Variabel $X 3$ dan $Y$

\begin{tabular}{|c|c|c|c|}
\hline & & $\begin{array}{l}\text { Kualitas } \\
\text { Layanan } \\
\text { Interaksi }\end{array}$ & $\begin{array}{l}\text { Kepuasan } \\
\text { Penggua }\end{array}$ \\
\hline \multirow{3}{*}{$\begin{array}{l}\text { Kualitas } \\
\text { Layanan } \\
\text { Interaksi }\end{array}$} & Pearson Correlation & 1 & .643 \\
\hline & Sig. (2-tailed) & & .000 \\
\hline & $N$ & 130 & 130 \\
\hline \multirow{3}{*}{$\begin{array}{l}\text { Kepuasan } \\
\text { Penggua }\end{array}$} & Pearson Correlation & .643 & 1 \\
\hline & Sig. (2-tailed) & .000 & \\
\hline & $N$ & 130 & 130 \\
\hline
\end{tabular}

Hasil uji korelasi variabel kualitas layanan interaksi $(X 3)$ terhadap kepuasan pengguna $(Y)$ memiliki nilai signifikansi lebih kecil dari " 0.05 ", maka antara kedua variabel memiliki hubungan atau korelasi. Nilai korelasi sebesar "0.643" juga menunjukkan bahwa kedua variabel memiliki derajat hubungan yang kuat atau positif.

Hasil uji korelasi berganda variabel kegunaan (X1), kualitas informasi (X2), dan kualitas layanan interaksi (X3) terhadap kepuasan pengguna $(Y)$ ditampilkan pada Tabel 8.

Tabel 8. Hasil Uji Korelasi Berganda

\begin{tabular}{cccccc}
\hline $\mathbf{R}$ & $\begin{array}{c}\text { R Square } \\
\text { Change }\end{array}$ & $\begin{array}{c}\text { F } \\
\text { Change }\end{array}$ & df1 & df2 & $\begin{array}{c}\text { Sig. } \\
\text { F Change }\end{array}$ \\
\hline $\mathbf{. 7 1 3}^{\text {a }}$ & .509 & 43.496 & 3 & 126 & $\mathbf{. 0 0 0}$ \\
\hline
\end{tabular}

Hasil uji korelasi berganda variabel kegunaan (X1), kualitas informasi (X2), kualitas layanan interaksi (X3), terhadap kepuasan pengguna $(Y)$ memiliki nilai signifikansi lebih kecil dari "0.05", maka setiap variabel secara simultan memiliki hubungan atau korelasi. Nilai korelasi sebesar " 0.713 " juga menunjukkan bahwa setiap variabel memiliki derajat hubungan yang kuat.

\subsection{Pengujian Hipotesis (Uji-t dan Uji-f)}

Tahap terakhir adalah pengujian hipotesis melalui pendekatan uji- $t$ dan uji- $f$. Proses uji- $t$ bertujuan untuk mengetahui pengaruh secara parsial (sendiri) variabel independen $(X)$ terhadap variabel dependen $(Y)$, dan uji- $f$ bertujuan untuk mengetahui 
pengaruh secara simultan (bersama) variabel independent $(X)$ terhadap variabel dependen $(Y)$. Hasil uji hipotesis setiap variabel disajikan sebagai berikut:

Hasil uji- $t$ dari variabel independen $(X)$ terhadap variabel dependen $(Y)$ ditampilkan padaTabel 9.

Tabel 9. Hasil Uji-I

\begin{tabular}{lccccc}
\hline & $\boldsymbol{B}$ & $\begin{array}{c}\text { Std. } \\
\text { Error }\end{array}$ & Beta & $\boldsymbol{T}$ & Sig. \\
\hline $\begin{array}{l}\text { Constant }) \\
\text { Kegunaan }\end{array}$ & -1.800 & 1.410 & & -1.277 & .204 \\
\hline $\begin{array}{l}\text { Kualitas } \\
\text { Informasi }\end{array}$ & .162 & .051 & .265 & 2.976 & $\mathbf{. 0 0 4}$ \\
$\begin{array}{l}\text { Kualitas } \\
\text { Layanan }\end{array}$ & .161 & .67 & .249 & 2.401 & $\mathbf{. 0 1 8}$ \\
\begin{tabular}{l} 
Interaksi \\
\hline
\end{tabular} & & & .281 & 2.660 & $\mathbf{. 0 0 9}$ \\
\hline
\end{tabular}

Hasil uji- $t$ setiap variabel independen terhadap variabel dependen memiliki nilai signifikansi kurang dari " 0.05 ", maka variabel independen secara parsial (sendiri) berpengaruh terhadap variabel dependen. Hasil uji- $t$ dikuatkan dengan hasil uji- $f$ yang ditampilkan Tabel 10.

Tabel 10. Hasil Uji- $f$ (ANOVA)

\begin{tabular}{lccccc}
\hline & Tabel 10. Hasil Uji- $f(\mathrm{ANOVA})$ & \\
\hline & Sum & $\boldsymbol{d f}$ & Mean & $\boldsymbol{F}$ & Sig. \\
\hline Regression & 434.256 & 3 & 144.752 & 43.496 & $\mathbf{. 0 0 0}^{\mathbf{b}}$ \\
\hline Residual & 419.321 & 126 & 3.328 & - & - \\
\hline Total & 853.577 & 129 & - & - & - \\
\hline
\end{tabular}

Hasil uji- $f$ setiap variabel independen terhadap variabel dependen memiliki nilai probabilitas kurang dari " 0.05 ”, maka variabel independen secara simultan (bersama) juga berpengaruh terhadap variabel dependen. Keseluruhan hasil pengujian hipotesis secara parsial dan simultan menghasilkan nilai yang sama yaitu variabel independen $(X)$ yang berpengaruh terhadap variabel dependen $(Y)$.

\section{KESIMPULAN}

Kesimpulan yang diperoleh dari hasil analisis pengujian adalah keseluruhan penyusunan hipotesis dapat diterima. Variabel independen yang terdiri dari kegunaan, kualitas informasi, dan kualitas layanan interaksi secara parsial maupun simultan berkorelasi, dan berhubungan kuat terhadap variabel dependen atau kepuasan pengguna. Nilai variabel independen yang semakin tinggi atau rendah akan bersesuaian dengan nilai variabel dependen. Hasil penelitian ini menunjukkan bahwa pengurus PKM Center Universitas Ahmad Dahlan harus memperhatikan variabel kegunaan, kualitas informasi, dan kualitas layanan interaksidi dalam website untuk meningkatkan kepuasan pengguna.

Hasil penelitian ini perlu dikaji secara lebih lanjut untuk mengidentifikasi faktor atau atribut yang menjadi prioritas pengembangan website PKM Center. Proses keberlanjutan penelitian dapat dilakukan dengan mengimplementasi pendekatan Importance Performance Analysis, dan Kano.

\section{UCAPAN TE RIMA KASIH}

Terimakasih kepada Lembaga Penelitian dan Pengabdian kepada Masyarakat di Universitas Ahmad Dahlan yang telah memberikan dana hibah untuk kegiatan penelitian ini dengan No. PDP-062/SP3/LPPMUAD/2020.

\section{REFERENSI}

[1] R. Alami, O. Hashemi Gorji, M. Shokri Asrami, H. Rasouli Saravi, M. Jafari Soteh, and F. Rajabi Ahangari, "The Role of Information Technology (IT) in Development and Increase of the Efficiency of Human Resources," Journal of Social Science Studies, vol. 3, no. 2, pp. 188-197, 2016.

[2] D. Grewal, J. Hulland, P. K. Kopalle, and E. Karahanna, “The Future of Technology and Marketing: A Multidisciplinary Perspective," Journal of the Academy of Marketing Science, vol. 48, no. 1, pp. 1-8, 2020.

[3] P. Sirikitsathian, S. Chaveesuk, and C. Sathitwiriyawong, "A Conceptual Framework for Better Understanding of Factors Influencing Accessibility to A Website and Its Acceptance by University Students with Visual Impairments," in 9th International Conference on Information Technology and Electrical Engineering (ICITEE), 2017, pp. 1-5.

[4] K. Marzuki, Apriani, and L. Z. A. Mardedi, "Evaluasi Penerapan Teknologi Informasi E-Learning Pada Kampus Swasta Menggunakan Cobit 4.1," Jurnal Bumigora Information Technology, vol. 1, no. 2, pp. 161-166, 2019. 
[5] J. Tarigan, "User Satisfaction Using Webqual Instrument: A Research on Stock Exchange of Thailand (SET)," Akuntansi dan Keuangan, vol. 10 , no. 1 , pp. 34-47, 2008.

[6] E. T. Loiacono, R. T. Watson, and D. L. Goodhue, "WebQual: A Measure of Web Site Quality," Marketing theory and Applications, vol. 13, pp. 432-438, 2002.

[7] S. J. Barnes and R. Vidgen, "WebQual: An Exploration of Website Quality," in European Conference on Information System (ECIS), 2000, pp. 1-9.

[8] S. J. Barnes and R. Vidgen, "An Integrative Approach To The Assessment Of E-Commerce Quality," Journal of Electronic Commerce Research, vol. 3, no. 3, pp. 114-127, 2002.

[9] S. J. Barnes and R. Vidgen, "Measuring Website Quality Improvements: A Case Study of The Forum on Strategic Management Knowledge Exchange,” Industrial Management \& Data Systems, vol. 103, no. 5, pp. 297-309, 2003.

[10] S. J. Barnes and R. Vidgen, "Data Triangulation in Action: Using Comment Analysis to Refine Web Quality Metrics," in European Conference on Information System (ECIS), 2005, pp. 1-13.

[11] S. J. Barnes and R. Vidgen, "Interactive E-Government: Evaluating the Web Site of the UK Inland Revenue," International Journal of Electronic Government Research, vol. 3, no. 1, pp. 19-37, 2007.

[12] F. Rindani and S. Puspitodjati, "Integration of Webqual Method to Importance Performance Analysis and Kano Model to Analyze System Quality of E-Government: Case Study LAPOR!," Jurnal Sistem Informasi, vol. 16, no. 2, pp. 1-17, 2020.

[13] Maryani, B. Mahesworo, A. S. Perbangsa, and H. Hendarti, "User Interface Evaluation on Government Knowledge Management Portal Using Webqual 4.0," in 2019 International Conference on Information Management and Technology (ICIMTech), 2019, pp. 244-249.

[14] N. A. Hidayah, A. Subiyakto, and F. Setyaningsih, "Combining Webqual and Importance Performance Analysis for Assessing A Government Website," in 2019 7th International Conference on Cyber and IT Service Management (CITSM), 2019, pp. 1-6.

[15] J. F. Andry, K. Christianto, and F. R. Wilujeng, "Using Webqual 4.0 and Importance Performance Analysis to Evaluate E-Commerce Website," Journal of Information Systems Engineering and Business Intelligence, vol. 5, no. 1, pp. 23-31, 2019.

[16] N. Adellia and A. Prasetio, "Customer Perception Mapping Analysis of Indonesian E-Commerce Marketplace Sites Based on Attributes Usability, Site Design, Information Quality, Trust, and Empathy (Case study of Tokopedia, Bukalapak, Elevenia, Qoo10, and Rakuten),” in 4th International Conference on Cyber and IT Service Management, 2016, pp. 1-7.

[17] J. Hasanov and H. Khalid, "The Impact of Website Quality on Online Purchase Intention of Organic Food in Malaysia: A WebQual Model Approach,” Procedia Computer Science, vol. 72, pp. 382-389, 2015.

[18] D. Napitupulu, “Analysis of Factors Affecting The Website Quality (Study Case: XYZ University),” International Journal on Advanced Science, Engineering and Information Technology, vol. 7, no. 3, pp. 792-798, Jun. 2017.

[19] M. Faizal and A. Prasetio, "Users' Expectation and Perception Gap Analysis of Telkom University Website with Modified WebQual 4.0 Method," International Journal of Information Science and Management, vol. 18, no. 2, pp. 1-18, 2020.

[20] Rismayani and Y. J. W. Soetikno, "Using WebQual 4.0 For Measuring Quality of E-learning Services During COVID-19 Pandemic," in 8th International Conference on Cyber and IT Service Management (CITSM), Oct. 2020, pp. 1-7.

[21] Sugiyono, Metode Penelitian Kuantitatif, Kualitatif, dan R \& D. Bandung - Indonesia: Alfabeta, 2019.

[22] D. A. Trisliatanto, Metodologi Penelitian. Yogyakarta - Indonesia: ANDI OFFSET, 2020.

[23] V. W. Sujarweni, Kupas Tuntas Penelitian Akuntansi dengan SPSS. Yogyakarta - Indonesia: Pustaka Baru Press, 2016. 
Matrik : Jurnal Manajemen, Teknik Informatika, dan Rekayasa Komputer, Vol. 20, No. 2, Mei 2021: 325 334 